\title{
JAPAN AND SOUTHEAST ASIA: FROM THE FUKUDA DOCTRINE TO ABE'S FIVE PRINCIPLES
}

\author{
Emilio de Miguel ${ }^{1}$ \\ Ministerio de Asuntos Exteriores y Cooperación (MAEC)
}

\begin{abstract}
:
The Fukuda Doctrine, announced in 1974, marked a new beginning in the relations of Japan with Southeast Asia and was determinant in their relations for the following decades. By the end of the 90s the combined pressures of Japan's stagnating economy and an emergent China showed the need of a reinvigorated strategy toward S.E.A. Primer Minister Junichiro Koizumi tried to bring about such a strategy and introduced new directions in two areas: security issues and economic partnership. Seven years after Koizumi, the new government of Shinzo Abe finds that the same geopolitical constraints of the late 90 s are still alive.
\end{abstract}

Palabras clave: Fukuda Doctrine, Japan, Southeast Asia, Rise of China, Abe’s Five Principles.

\section{Resumen:}

La doctrina Fukuda, anunciada en 1974, marcaba un nuevo inicio en las relaciones de Japón con el Sureste Asiático y fue determinante para las relaciones mutuas en las décadas posteriores. Para finales de los años 90 , las presiones combinadas de una economía estancada y una China emergente, mostraban la necesidad de una estrategia más activa hacia el Sureste Asiático. El primer ministro Junichiro Koizumi trató de plasmar tal estrategia e introdujo dos nuevas direcciones en dos áreas determinadas: asuntos de seguridad y asociación económica. Siete años después de Koizumi, el nuevo gobierno de Shinzo Abe se encuentra con que las mismas limitaciones geopolíticas de finales de los 90 se mantienen.

Keywords: Doctrina Fukuda, Japón, Sureste Asiático, auge de China, Cinco Principios de Abe.

Copyright @ UNISCI, 2013.

Las opiniones expresadas en estos artículos son propias de sus autores, y no reflejan necesariamente la opinión de UNISCI. The views expressed in these articles are those of the authors, and do not necessarily reflect the views of UNISCI.

\footnotetext{
${ }^{1}$ Emilio de Miguel Calabria es Consejero Técnico en la dirección general del Sureste Asiático, Pacífico y Filipinas en el Ministerio de Asuntos Exteriores de España.

E-mail: emilio.demiguel@maec.es.
} 


\section{Introduction}

The relations of Japan with Southeast Asia till the end of the 60's evolved in the framework set by the Yoshida Doctrine that encompassed the following parameters: 1) Reliance on the alliance with the United States to ensure Japan's security, following the signing of the 1954 Mutual Defense Assistance Treaty; 2) Emphasis on economic relations; 3) Low profile in international politics ${ }^{2}$.

In the case of S.E.A. this parameters were compounded by the need to normalize the relations through the reparations for the Japanese occupation during II World War. Japan signed Reparation and Economic Agreements with Burma, Indonesia, the Philippines and Vietnam. The reparations amounted to around 2 billion US dollars at 2013 rates and were discontinued in 1976. Japan was allowed to make reparations in kind so that the reparations turn out to pave the way for the future export of Japanese goods and services. Also some minor amounts were given to Cambodia, Laos and Thailand, listed as economic assistance, not as compensation for damages done during II World War.

By the end of the sixties and the early seventies this approach to Southeast Asia had reached its limits. The Ministerial Conference for the Economic Development of Southeast $\mathrm{Asia}^{3}$, convened for the first time in Tokyo in 1966, showed that the countries in the region were reluctant to let Japan play a conspicuous role in S.E.A. The Vietnam War and its aftermath were changing the geopolitics of the region. The rapprochement between Washington in Beijing in 1973 introduced a new balance of power in the region. The embryo of a regional architecture had made its appearance with the creation of ASEAN in 1967. In later years, specially after the 1976 Bali Summit ASEAN countries became more selfconscious and ready to play a role in the international arena. The countries of the region were progressing in their industrialization and economic diversification efforts. Along the way, the countries were opening their economies and introducing some market-oriented reforms. The kind of passive and mostly economic approach preached by the Yoshida Doctrine could not cope with such a changing environment. It was then that the so-called Fukuda Doctrine was formulated.

\section{The Fukuda Doctrine}

The need of a new approach became evident during the visit that Prime Minister Tanaka made to the Philippines, Thailand, Singapore, Malaysia and Indonesia from January 7 to 171974. That was the first visit by a Japanese Prime Minister since the tour of Prime Minister Sato in 1967. Seven years is an eternity in foreign relations.

Tanaka's visit was a debacle in terms of image. In Jakarta thousands of students took the streets in protest. In the following riots eleven persons were killed. In Bangkok he was

\footnotetext{
${ }^{2}$ A good discussion on the Yoshida Doctrine and its implication for Japan's foreign policy during the Cold War can be found in "Política Exterior de Japón en la Posguerra," by Potter, David M., in Rubio Díaz-Leal, Laura (ed.) (2008): China y Japón: Modernización Economica, Cambios Políticos y Posicionamiento Mundial, Ciudad de México, Editorial Castillo.

${ }^{3}$ Of the nine countries invited, Burma refused the invitation and Cambodia and Indonesia sent only observers. For a discussion about the rationale behind the convening of the Conference see Terada, Takashi: "The Japanese Origins of PAFTAD: The Beginning of an Asia Pacific Economic Community”, Pacific Economic Paper, n 292 (June 1999).
} 
received at their airport by protesters with banners saying "Get out ugly imperialist". Even if domestic considerations fuelled partly the protests, the impact for the Japanese policy-makers was important.

Tokyo's 1974 "Diplomatic Bluebook" stated: "Criticism of Japan has increased in various Southeast Asian countries in recent years against its sharply increased enormous economic presence, the business methods of Japanese enterprises and also the behaviour of Japanese residents in those countries ${ }^{4}$. On the occasion of the Primer Minister's visit, local students staged anti-Japanese demonstrations and riots in Bangkok and Jakarta. Protests also occurred in Malaysia and elsewhere." The Bluebook was somewhat aware that S.E.A. countries wanted to go beyond mere economic relations ${ }^{5}$, but fell short of suggesting which design a renewed Japanese policy to Southeast Asia should adopt.

The events of 1975 made unavoidable a change of course. Saigon, Phnom Penh and Vientiane fell to communist forces. United States wanted to disengage partially from S.E.A. and wished Japan to increase its political role in the region. ASEAN was becoming a fullfledge actor in the region. The new policy to cope with these challenges was the Fukuda Doctrine.

In August, 18th 1977, during a visit to Manila, Prime Minister Takeo Fukuda gave a speech in which set the new principles that would guide the Japanese policy to Southeast Asia. Those principles as stated in the "Diplomatic Bluebook for 1977" are: "1) Japan is committed to peace, and rejects the role of a military power; 2) Japan will do its best to consolidate the relationship of mutual confidence and trust based on "heart-to-heart" understanding with the nations of Southeast Asia, 3) Japan will cooperate positively with ASEAN while aiming at fostering a relationship based on mutual understanding with the countries of Indochina and will thus contribute to the building of peace and prosperity throughout Southeast Asia. ${ }^{6}$ " In other words: 1) Japan renounced to play any military role in the region, assuaging any fears coming form History; 2) Japan was aware of the limitations of an approach based only in the economy and was willing to undertake a multi-dimensional approach, encompassing politics, culture and people-to-people; 3) Japan was ready to contribute to the healing of the divide in Indochina, after the Vietnam War and the Vietnamese invasion of Cambodia.

\footnotetext{
${ }^{4}$ In this respect the impact of Japanese sex tourists on the image of their country cannot be denied. According to Yoshimi Yoshiaki (Yoshiaki, Yoshimi (2000): Comfort women: sexual slavery in the Japanese military during World War II, New York, Columbia University Press): “... Japanese male sex tourists travelling abroad outnumber those of other nations."

${ }^{5}$ The Bluebook, for instance, stated: “... the Southeast Asian countries need Japan's aid or economic strength for their own nation-building efforts and, in this context, they are showing the basic posture of placing increasing expectations on Japan's cooperation..." and "... the common understanding was reaffirmed that it was necessary to promote such relations further in a constructive manner in the direction of mutual benefit."

${ }^{6}$ This formal formulation of the Doctrine doesn't make justice to the more passionate speech of Fukuda. In his own words: "Diplomacy toward Southeast Asia until now was contact through money and goods. It was not contact based on the policy of good friends acting for mutual benefit. Even when viewed from our country there was an impression of economic aggression and arrogant manners, and it was a situation which was symbolized by the expression economic animal."
} 


\section{The aftermath of the Fukuda Doctrine}

The Fukuda Doctrine and its potential became soon visible in three areas: 1) Bridging the gap between the ASEAN countries and the three Communist States in Indochina; 2) Serving as economic model and helping the ASEAN economies through ODA and FDI; 3) Promoting Japanese soft power.

\subsection{Bridging the Gap in Indochina}

In the aftermath of the end of the Vietnam $\mathrm{War}^{7}$, the Japanese assumption was that Vietnam, Laos and Cambodia ${ }^{8}$ would be amenable to a compromise in exchange of western aid. The "Diplomatic Bluebook for 1975 defined Japan's policy to the three Indochinese countries this way: "It is the policy of Japan to establish good relations with the three countries of Indochina where socialist regimes have been established by transcending the difference in political and social systems. It is considered that Japan's assistance in the postwar reconstruction and development of Indochina will contribute to the peace and development of that region and thereby of Southeast Asia as a whole."

In that spirit, Japan made a contribution of 5.3 million dollars ${ }^{9}$ to the Indochina Emergency Assistance Program of the International Red Cross in 1975 and over 3 million dollars to the UNHCR for relief activities for Indochina refugees abroad. Japan also granted an aid of 21.500 million dollars to Vietnam in that same year and extended to Laos an additional credit for the Second Nam Ngum Development Fund. In subsequent years Japan settled the question of the Government of South-Vietnam debt to Japan and gave a grant of 55 million dollars for the purchase of Japanese equipment and materials necessary for the postwar reconstruction of the country. Concerning Laos, in 1976 Japan granted an additional loan of over 4 billion dollars for the second-stage construction of the Nam Ngum Dam. Till a certain point, Japan was replicating what had been its policy to S.E.A. in the Fifties and Sixties.

This policy broke down when at the end of 1978 Vietnam invaded Cambodia and the international community led by U.S. and China and also by most ASEAN countries condemned the invasion. In April 1979 Japan notified unofficially Vietnam the freeze of all assistance. Subsequently Japan would refuse to recognize the Heng Samrin Government set by Vietnam in Phnom Penh and would continue to consider the Government of Democratic Kampuchea in exile the legitimate one. Most likely Japan would have preferred a softer stance to Vietnam as shown by its efforts to keep the channels of dialogue open, but it was unwilling to adopt a high-profile and marked position ${ }^{10}$.

This episode showed that, even with the Fukuda Doctrine, Japan was not ready to assume political protagonism, especially if it meant parting ways with US. At that moment

\footnotetext{
${ }^{7}$ In the last stages of the war, after the Paris Peace Accords and once the eventual demise of South Vietnam became a possibility, Japan tried to have a more balanced approach and establish diplomatic relations with North Vietnam in September 1973; See: Shiraishi, Masaya (1990): Japanese relations with Vietnam: 1951-1987, Ithaca; New York, Cornell University.

${ }^{8}$ Japan had established diplomatic relations with then North Vietnam in September 1973. It had relations with Laos since March 1955 which were not discontinued during the regime of the Pathet Lao. Relations with Cambodia were discontinued by the government of the khmer rouge when it took power in April 1975 and then restored in August 1976.

${ }^{9}$ Unless otherwise expressed, all amounts are given in 2012 dollars.

${ }^{10}$ Shiraishi, Masaya: "Japan toward the Indo-China Subregion", Journal of Asia-Pacific Studies, no. 13 (October 2009), pp. 13-36.
} 
there was still a big gap between Japan's economic power and the political projection of that power in the international arena.

\subsection{Japan as Economic Model and the Role of its FDI and ODA}

The economic crisis of the 70s imposed some changes on the economic strategy of Japan, that made an effort to diversify its supply sources so not to be dependent on one specific supplier. Furthering the interests of Japanese business became an important component of the foreign policy of Japan. Accordingly Ministries such as Ministry of Finance, the Ministry of International Trade and Industry (since 2001, Ministry of Economy, Trade and Industry) or the Ministry of Posts and Telecommunications acquired a strengthened role in the formulation of the foreign policy to the detriment of the Ministry of Foreign Affairs ${ }^{11}$.

These changes coincided with some transformations in the so called "flying geese" pattern of development ${ }^{12}$. Japanese decision-makers could assume in the 70s that Japan had reached the third stage of the model, so that labour-intensive industries started being transferred to S.E.A. The first industries to be transferred were textiles followed by basic electronics and vehicle-assembly. S.E.A. countries, embarked in their own industrialization process were eager, to receive Japanese FDI. The convergence of interest between Japan and the receiver countries plus the synergy between FDI and ODA helped to foster the economic links between Japan and S.E.A. and to enhance the image of Japan in the region ${ }^{13}$.

By 1980 over $30 \%$ of total Japanese ODA was directed to S.E.A. countries. The ODA would focus in improving the infrastructures of S.E.A. ${ }^{14}$ while promoting the penetration of Japanese companies and paving the way for FDI. The amount of ODA increased since 1978, when Japan set the Medium-term goal, a five-year quantitative target to increase its volume. The main recipient of Japanese ODA in S.E.A. was Indonesia and focused in natural resource projects. Thailand and the Philippines came in second and third places with similar amounts of ODA, with a volume that was $50 \%$ of the one of Indonesia. Malaysia was a distant fourth recipient at roughly $25 \%$ of the volume directed to Indonesia.

\footnotetext{
${ }^{11}$ Potter, op. cit.

${ }^{12}$ The "flying geese model" was made popular by Kaname Akamatsu in his article: "A historical pattern of economic growth in developing countries", Journal of Developing Economies, vol. 1, no. 1 (March-August 1962): Akamatsu described the process of Asian countries catching up with the West as a flock of flying geese: the different Asian countries would shift from production models based on high intensity of labour to capitalintensive ones in a hierarchical way so that the less developed countries would follow the most developed ones in the region. Japan would be the leading goose. The second tier would be the New Industrialized Countries (South Korea, Taiwan, Singapore and Hong Kong). The third tier would be composed by the main ASEAN countries (Philippines, Indonesia, Thailand and Malaysia). In the rearguard there would be China. A good technical discussion of the model can be found in: Kojima, Kiyoshi: "The "flying geese" model of Asian economic development: origin, theoretical extensions, and regional policy implications", Journal of Asian Economics, vol. 11, no. 4 (2000), pp. 375-401; not every economist, especially in the Anglo-Saxon world would agree with this model. The point is that by the late 60s this model was already very influential among Japanese decision-makers and it continued to be so, either in its original Akamatsu's version or in its Kojima's adaptation. ${ }^{13}$ A good discussion on this can be found in: Patrick, Hugh: "Legacies of Change: The Transformative Role of Japan's Official Development Assistance in its Economic Partnership with Southeast Asia”, APEC Study Center, Columbia University, Discussion paper, nº54 (January 2008).

${ }^{14}$ According to OECD, in $1973 / 74,59,1 \%$ of Japan's ODA was devoted to infrastructures, divided roughly equally between economic and social infrastructures. In 1979/80, the percentage was of 74,15\%, of which two thirds went to economic infrastructures.
} 
During the 80s, FDI would become progressively more relevant. This process accelerated after the Plaza Accord of 1985, that appreciated the yen and gave an incentive to Japanese companies to produce abroad. The main beneficiaries of this increased FDI flows were Indonesia, Singapore and Thailand. By 1992 Japan had overtaken the US as the largest investor in S.E.A., except in the Philippines.

Summarizing, the combination of the Fukuda Doctrine and the changes in Japan's economy led to a deepening of the economic linkages with S.E.A. Asia so that by the early 90's Japan was the main economic partner of the region.

\subsection{Promoting Japanese Soft Power}

The Fukuda Doctrine was born partly out of the concern for Japan's image in S.E.A. Kazuo Ogoura has described the situation first found by Fukuda thus: "The 1970s brought another shift in Japan's cultural diplomacy, this time in response to the rise of an anti-Japanese sentiment in Asia, as typified by the eruption of feelings in Southeast Asia against the perceived Japanese economic onslaught. Rapidly increasing economic dependence on Japan in terms of trade, investment, and development assistance provoked a backlash in many parts of Asia. Some people sarcastically labelled the country "Faceless Japan" or "Banana Japan", the latter implying that the Japanese did not understand Asia because they were yellow on the outside (Asian in appearance) but white on the inside (Western in thinking). Others complained that Japan was always represented by Sony and Honda or by the yen note, without any direct person-to-person contacts with its Asian partners." 15

These misperceptions had an influence in the way Japan chose to project its soft power, even before that expression had been invented. It has already been mentioned how FDI and ODA, two elements of soft power, evolved in the aftermath of the Fukuda Doctrine. Now it is the turn to focus on the socio-cultural aspects of Japan's soft power ${ }^{16}$.

In 1977 the ASEAN Cultural Fund with an amount of 250 million US dollars was founded to promote intra-ASEAN cultural exchanges as well as between ASEAN countries and third parties. In 1979 the Southeast Asia Youth Invitation Program was set in order to promote better mutual understanding through the invitation of outstanding young Southeast Asian leaders to Japan. Also a Japan Scholarship Fund for ASEAN Youth for an yearly amount of 3 million dollars was instituted. Other initiatives were: the Human Resources Development Project (1981); the Japan-ASEAN Research Cooperation Fund (1982) to promote intra-ASEAN area studies and Japan-ASEAN academic exchange; the ASEANJapan Friendship Program for the $21^{\text {st }}$ Century (1983) to promote students trips and exchanges.

The soft-policy strategy adopted then used more or less traditional tools and was boosted by two factors: 1) Japan had become the second biggest world economy and it had become a model for Asian countries; 2) There were no other Asian countries capable of making such an use of soft-power. As we will see later, these advantages didn't survive to the beginning of the $21^{\text {st }}$ century.

\footnotetext{
${ }^{15}$ Ogura, Kazuo (2009): Japan's Cultural Diplomacy, Past and Present, Tokyo, Japan Foundation.

${ }^{16}$ A list of soft-power initiatives can be found in Lam, Peng Er (2013): "Japan's Relations with Southeast Asia: The Fukuda Doctrine and Beyond", London, Routledge.
} 


\section{Primer Minister Nobuo Takeshita and the New Partnership for Peace and Prosperity}

1987 marked the $20^{\text {th }}$ anniversary of the Bangkok Declaration that created ASEAN and the $10^{\text {th }}$ anniversary of the Fukuda Doctrine. The recently elected Prime Minister Noburo Takeshita chose the ASEAN Summit held in Manila in December of 1987 as the destination of his first official overseas trip. Prior to his trip a large-scale Cultural Mission travelled to S.E.A. in November 1987. This is symptomatic of the increasing relevance of soft power and image issues in the way Japan chose to project itself in S.E.A.

In Manila Takeshita announced a New Partnership for Peace and Prosperity to support ASEAN development. This announcement was materialised in:

+ The creation of a 4 billion US dollars Japan-ASEAN Development Fund. The Fund had two components: loans to the private sector for joint venture projects in the region at a low-interest of $3 \%$ per annum and untied loans to the development institutions of the ASEAN countries.

+ The Japan-ASEAN Comprehensive Exchange Program aimed at promoting further exchanges between civil societies and the academe. As a complement to this program, new offices of the Japan Foundation were opened in the ASEAN countries and an ASEAN Cultural Center was opened within the Japan Foundation.

+ The Japan-ASEAN Investment Fund established in January 1988.

To understand the rationale behind these initiatives it is interesting to refer to the speech Takeshita gave in Jakarta in May 1989 at the end of his Premiership under the title: "Japan and ASEAN: thinking together and advancing together":

"Soon after becoming Prime Minister of Japan, I have set forth and International Cooperation Initiative premised in the following three pillars. The first pillar is the strengthening of cooperation to achieve peace. The second is the expansion of Japan's Official Development Assistance. And third is the strengthening of international cultural exchange. I believe that South East Asia is one of the most important areas for this International Cooperation Initiative and I intend to promote actively the initiative in the region". 17

During the 80s, that golden age of Japan's economy, it had become clear that Japan was not playing an international role commensurate with its economic stature. Besides that Japan needed to assuage the fears and anxieties provoked by its rise, so the new focus on its image and soft power. ${ }^{18}$ S.E.A. became the choice ground to show the constructive and active role

\footnotetext{
${ }^{17}$ Sudo, Sueo (2002): “The International Relations of Japan and South East Asia: Forging a New Regionalism”, London, Routledge.

${ }^{18}$ Some excerpts for the 1990 Diplomatic Bluebook will show how this issue was perceived by the Japanese themselves: "...Japan should realize that the sense of distrust and fears for Japan has tended to increase as its economic power and influences grow (...) in the face of the mixed feelings of expectations and fears about Japan, Japan must not only make utmost efforts to contribute to world peace and prosperity, but also endeavours to secure the understanding of other countries about its position and efforts by explicitly stating
} 
Japan was ready to play internationally. That was in substance the rationale behind the policies of Takeshita. A good occasion to put these ideas into practice would be the Cambodian Peace Process, where Japan played a relevant role.

\section{The Cambodian Peace Process}

The comparison between Japan's role in Indochina in the late 70s and in the early 90s is significant. Then Japan chose to follow Washington's indications instead of defining its own policy course. In the early 1990 Japan felt confident enough as to play a substantial role in the solution of the Cambodian conflict. As then Prime Minister Tshiki Kaifu said: "I feel acutely that Japan is expected to make even greater contributions in the Asia-Pacific region- not only in the economic sphere, but in the political sphere as well."19

In June 1990 Japan sponsored the Tokyo Conference where the four warring factions met together in order to explore a peace settlement. As Foreign Minister Nakayama told at the ASEAN Post-Ministerial Conference held in Kuala Lumpur on July, 22 1991, the convening of the Tokyo Conference was a good example of Japan's will to play a more active political role in order to ensure regional stability. Later, Japan, together with Thailand, was instrumental to convince the khmer rouge to accept the 1991 Paris Peace Agreement.

Japan's role was also to secure the resources needed for the implementation of the Agreement. In June 1992 Japan convened the Ministerial Conference on the Rehabilitation and Reconstruction of Cambodia, where assistance totalling 1,4 billion dollars was pledged. Japan pledged $20 / 25 \%$ of the total. Japan co-chaired the first meeting of the International Committee on the Reconstruction of Cambodia (ICORC), held in Paris in September 1993, and organized in Tokyo the second meeting of the ICORC in March 1994. Japan also contributed to the reconstruction of Cambodia through the bilateral channels of its ODA, being the largest donor since $1994 .^{20}$

As a novelty that required the passing of a new law, the International Peacekeeping Operations Law, Japan also sent a construction unit of its Self-Defense Forces, civilian police officers and military observer to join the United Nations Transitional Authority in Cambodia (UNTAC). In total roughly 1.300 Japanese police and military personnel took part in UNTAC. The Japanese national Yasushi Akashi was the head of the peacekeeping mission as recognition of the prominent role played by Japan.

Unexpectedly and in spite of the success of UNTAC, Japan renounced to play such a prominent role in other crisis arising in S.E.A. in the 90s and early $21^{\text {st }}$ century. It played a mute and secondary role in the Mindanao peace process to other actors such as Malaysia or Libya. In Myanmar it followed an ambivalent approach never putting too much pressure on the military regime, but never breaking ranks with the Western like-minded countries. Most

them." The Bluebook then stressed the importance of public diplomacy, of promoting the internationalization of its society and of contributing to the maintenance of international order.

19 Vatikiotis, Michael: “Kaifu soothes fears over Japan's political plans: The Gentle Giant", Far eastern Economic Review, 16 May 1991.

${ }^{20}$ In 1993, 1994 and 1995 ODA amounted respectively to 97 million \$, 102 million \$ and 242 million. Besides that, Japan made contributions both bilaterally and multilaterally to the safeguarding and development of the historical, site of Angkor Wat. 
tellingly, especially when compared to the Cambodian case, Japan was only one of many contributors to East Timor after the independence referendum of 1999.

\section{Beyond Cambodia: Japan's Contribution to the Building of a Regional Architecture in S.E.A.}

\subsection{ASEAN Regional Forum}

The Cambodian conflict highlighted the role ASEAN could play as the meeting point and facilitator of talks between the great powers involved in the region. It was a seminal moment for the creation of a regional architecture in S.E.A. with ASEAN at its center ${ }^{21}$. Japan became deeply involved in the regional architecture processes engaged in the 90s as they fitted with the new international role for the country promoted by Prime Minister Takeshita.

In fact, the first suggestion of what later would become the ASEAN Regional Forum (ARF) came from the Japanese Foreign Minister Taro Nakayama. During his speech to the General Session of the ASEAN Post-Ministerial Conference held in Kuala Lumpur on July, 22 1991, Nakayama sketched a possible model for a regional architecture in Asia-Pacific based in the existing international fora, especially those concerned with economic cooperation, "that is the most vital element in regional security": ASEAN, AEAN PostMinisterial Conference, APEC and PECC (Pacific Economic Cooperation Council). These for a could be complemented with a "forum for political dialogue where friendly countries in this region could engage in frank exchanges of opinion on matters of mutual interest". The ASEAN Post-Ministerial Conference could be, according to Nakayama, such a political forum "for addressing the regional peace and security issues". Nakayama suggested the organization of a senior officials' meeting that would report to the ASEAN Post-Ministerial Conference for further discussions.

Mala Selvaraju ${ }^{22}$ has explored how this initiative was most convenient for both ASEAN and Japan's interests. Because of its economic interests Japan needed a peaceful and secure S.E.A. The international geopolitical situation had changed: US remained the sole, but not omnipotent superpower and its willingness to be deeply engaged in the region was not granted; the Soviet Union, and later Russia, had decreased its involvement in S.E.A.; China was emerging as a main player at least in the region. Because of misgivings arising of History, Japan wanted to show its readiness to tackle security issues from a peaceful and cooperative instance. Therefore, a multilateral approach with ASEAN taking the lead, seemed the best solution. For ASEAN, this kind of forum could serve to reduce tensions between its members and promote friendly relations with and between the great powers. An added value for both ASEAN and Japan was that this approach allowed to keep US engaged with the region in security issues.

\footnotetext{
${ }^{21}$ Chanto, Sisowath Doung: "The ASEAN Regional Forum- The Emergence of "Soft Security": Improving the Functionality of the ASEAN Security Regime", Cambodian Institute for Cooperation and Peace, Dialogue + Cooperation (3/2003), offers a good discussion on the process leading to the creation of the ASEAN Regional Forum (ARF), the first multilateral forum on security that appeared in Asia-Pacific.

${ }^{22}$ Selvaraju, Mala: "Diplomatic Issues in Japan-ASEAN Relations", Journal of Southeast Asian Studies, vol. 6, Iss. 1 (December 2001), pp. 105-118, at http://e-journal.um.edu.my/filebank/published article/4317/5.\%20105118\%20Mala\%20Selvaraju..\%20Diplomatic\%20Issues\%20In\%20Japan-ASEAN..\%20Jati\%206.pdf.
} 
This confluence of interests allowed the creation of the ASEAN Regional Forum (ARF) in 1994. The members of the ARF where ASEAN and its Dialogue Partners ${ }^{23}$. Its objectives, as stated in the First ARF Chairman's Statement were: "1. To foster constructive dialogue and consultation on political and security issues of common interest and concern; and 2. to make significant contributions to efforts towards confidence-building and preventive diplomacy in the Asia-Pacific region."

\subsection{The Asian Crisis and the Emergence of ASEAN + 3}

By 1997 Japan seemed to be well positioned in S.E.A. in spite of the high turnover of its Prime Ministers and the problems with its economy. In January that year Prime Minister Ryutaro Hashimoto visited several ASEAN countries. In Singapore, his last stop, Hashimoto gave a speech where he defined how he envisaged a deepened and broadening Japan-ASEAN relationship for the $21^{\text {st }}$ century. The three pillars he highlighted for such an achievement were: 1) Broader and deeper exchanges between Japan and ASEAN at the top and other levels; 2) Multilateral cultural cooperation aimed at the preservation of each country's unique cultures and traditions; 3) Promotion of joint endeavours to address global challenges such as environment, terrorism, health and welfare and drug trafficking. ${ }^{24}$ Hashimoto went further than anything proposed by previous Japanese Prime Ministers, as he suggested the holding of regular political summits with ASEAN and bilateral talks on security issues.

Japan had a chance to show its new assertiveness when was asked, together with France, to mediate between the two Cambodian Co-Prime Ministers, Hun Sen and Ranariddh in June 1997. The fragile arrangement reached was broken the following month and a fierce fighting ensued. The crisis finished with the flight of Ranariddh from Cambodia and Hun Sen becoming the sole Prime Minister of the country. Interestingly Japan followed its own line and refused to follow US admonitions to suspend all ODA. ${ }^{25}$ Japan later facilitated the arrangement between Ranariddh and Hun Sen that allowed the first one to go back to Cambodia and run the general elections in July 1998.

The Asian financial crisis started early July 1997 in Thailand and expectations about the role Japan could play were high. Japan's first reaction was a conventional one: it offered assistance to the bail-out packages planned by the IMF, as the 4 billion $\$$ it announced would provide to Thailand in August and the 5 billion to Indonesia in November.

Then, in August Japan came with a revolutionary idea: the creation of an Asian Monetary Fund. The AMF would be a 100 billion \$ fund. Its members would be: Australia, China, Hong Kong, Indonesia, Japan, Malaysia, Philippines, Singapore, South Korea and Thailand. As a show of the new assertiveness of Japan, US was neither invited nor consulted previously and it was stated that the AMF would not necessarily coordinate its activity with the $\mathrm{IMF}^{26}$.

\footnotetext{
${ }^{23}$ The current participants in the ARF are the 10 ASEAN countries plus Australia, Bangladesh*, Canada, China, DPRK*, European Union, India, Indonesia, Japan, Mongolia*, New Zealand, Pakistan*, Papua New Guinea*, Republic of Korea, Russia, Sri Lanka*, Timor-Leste* and US. Those countries with * are not Dialogue Partners of ASEAN.

${ }^{24}$ At the webpage of the Japanese MOFA (http://www.mofa.go.jp/region/asia-paci/asean) several documents concerning this visit can be consulted.

${ }^{25}$ Sothirak, Pou; Wade, Geoff and Hong, Mark (eds.) (2012): Cambodia: progress and challenges since 1991, Singapore, Institute of Southeast Asian Studies.

${ }^{26}$ This statement would be softened later when trying to make the AMF more palatable to US.
} 
The AMF was scuttled during the Regional Financial Minister's meeting held in Hong Kong on November $21^{\text {st }} 1997$. The opposition of US to an initiative where it had no role and where the IMF was sidelined plus the lack of support of China, fearful of a confident Japan, torpedoed the AMF. Instead of the AMF, the so-called Manila Framework, less ambitious and IMF-centered, was created. ${ }^{27}$

It would take Japan one year to come out with a different initiative. In October 1998 Minister of Finance Kiichi Miyazawa announced the so-called New Miyazawa Initiative. Japan set a fund of 30 billion US\$. Half of it would be available for the medium to long-term financial needs of the economic recovery of the Asian countries; the other half would cover short-term capital needs during the implementation of the economic reforms. ${ }^{28}$

From the political side, the New Miyazawa Initiative can be seen as an attempt to recover the leadership role in the solution of the Asian financial crisis, that had lost the previous year. The New Miyazawa Initiative was successful from a technical point of view and allowed Japan to show a certain independence vis-à-vis US and the IMF, for instance making of Malaysia, which was following policies opposed to the IMF orthodoxy, one of the main beneficiaries of the Initiative. Nevertheless, in terms of image it could not make up for the withdrawal of the AMF the previous year that had showed Japan to be a reluctant leader. In comparison, China's image came out strengthened with its decision no to devalue its currency and its extension of financial aid to Thailand and Indonesia, even if its volume was lesser than the one provided by Japan ${ }^{29}$.

In parallel to the different initiatives to help S.E.A. economies to cope with the effects of the crisis, the relationships between ASEAN and the three countries of East Asia were institutionalized.

In December 1997 the first Japan-ASEAN Summit meeting was hold in Kuala Lumpur in order to materialize the new relationship Primer Minister Hashimoto had envisioned during his January trip. As promised, the summit opened new areas to dialogue: environment, energy, international terrorism, international organized crime, health and welfare. Global and regional security issues were reviewed and it was agreed to cooperate closely on them in international fora. In spite of its broad scope and its ambition, the Summit was somehow overshadowed by the convening of the first ASEAN + 3 (China, Japan and Korea Summit). ASEAN + 3 was formally institutionalized during its third summit which was held in Manila in November 1999.

\subsection{An assessment of Japan-S.E.A relations in the $90 \mathrm{~s}$}

It is usually asserted that the 90s were a lost decade for Japan's economy. Something similar could be told of Japan's relationships with ASEAN during those years.

In the early 90s it seemed as if Japan had finally the will to develop a foreign policy equal to its economic stature. S.E.A was the first place to test this new will and Japan passed the exam with honours in Cambodia. Japan's involvement and meaningful role in the inception of a regional architecture was a consequence of its success in Cambodia. The new

\footnotetext{
${ }^{27}$ Lipscy, Phillip Y.: “Japan's Asian Monetary Fund Proposal”, Stanford Journal of East Asian Affairs, vol. 3, no. 1 (Spring 2003)

${ }^{28}$ Specific details of the working of the fund can be found in the webpage of Japan's MOFA.

${ }^{29}$ A legacy of these initiatives would be the Chiang Mai Initiative of 2000 that is out of the scope of this article.
} 
turn to the Japan-ASEAN relationship that Prime Minister Hashimoto envisioned was the natural evolution in this process. Then the Asian financial crisis came.

The Asian financial crisis showed the shortcomings of Japan's leadership. The episode of the AMF was reminiscent of the shyness deployed by Japan in the late 70s in Indochina. Japan's prestige in the region never recover fully from the failure to create the AMF because of the US opposition. In contrast China managed to use the Asian financial crisis as an opportunity to introduce herself as a meaningful player in the region. Japan was neither able nor willing to stop this development. The creation of ASEAN + 3 meant that Japan could not invoke for itself the role of main Asian interlocutor of the region anymore.

\section{The relationship with S.E.A. during the government of Koizumi}

\subsection{General Plan}

Japan's foreign policy during the five years that Junichiro Koizumi was Prime Minister (April 2001- September 2006) was marked by several developments:

1. 11-S and its aftermath that made security concerns and counter-terrorism come to the forefront of the international agenda.

2. US, under the Bush Administration, trying to reassert its status as the sole superpower and opting for unilateral actions instead of resorting to multilateral fora. This more active and even forceful presence in the global arena went hand by hand with a lessening of its presence in Asia-Pacific.

3. A increasingly self-confident China appearing as a major actor and competitor in the region.

4. An economy weakened by the so-called "lost decade". This had not only economic implications, but also had a strong influence on the image of Japan and how it was perceived by other international actors, as well as being the cause for the decrease in the ODA since the end of the 90 s.

5. Changes in the concept of soft-power. Japan's soft-power incorporated more and more new cultural expressions, such as manga, videogames...

How did Koizumi reacted to this changed environment? Formally he adopted a more nationalist stance, a closer relationship with US and a more proactive attitude in international affairs, specially in security issues and counter-terrorism. But discontinuities with previous Prime Ministers were more apparent than real. Koizumi didn't mean any substantial break in the traditional lines of Japan's foreign policy. Pragmatism was the norm as usual ${ }^{30} 31$.

\footnotetext{
${ }^{30}$ Heginbotham, Eric and Samuels, Richard J.: "Japan's Dual Hedge”, Foreign Affairs (September/October 2002).

${ }^{31}$ A very good article on the redefinition of Japan's strategy brought by Koizumi is Tang, Siew Man: “Japan's Grand Strategic Shift from Yoshida to Koizumi: Reflections on Japan's Strategic Focus in the $21^{\text {st }}$ Century", Akademika, no. 70 (2007), pp. 117-136, at
} 
Koizumi unveiled his plans for S.E.A. in the speech "Japan and ASEAN in East Asia- A Sincere and Open Partnership" ${ }^{32}$, that he delivered in Singapore, on the $14^{\text {th }}$ of January 2002, at the end of his tour by the 5 original ASEAN countries ${ }^{33}$. The main points of his speech were:

1. The need of reforms to create the new economic structures required by the $21^{\text {st }}$ century. Koizumi offered Japan's cooperation to provide the ASEAN countries with the needed capabilities. Koizumi identified the Mekong Subregion as an area of special interest because of the less developed status of its members. Among the ASEAN initiatives of major interest Koizumi highlighted the ASEAN Free Trade Area and the ASEAN Investment Area.

2. Japan's readiness to contribute to the stability of the region, even through the dispatching of Self Defense Force units. Specific cases of interest he mentioned were Mindanao, Aceh and East Timor. Koizumi suggested even to establish Japan-ASEAN cooperation to promote stability worldwide, proposing Afghanistan as the trial ground.

3. Five concrete initiatives: 1) Exchange and cooperation between universities; 2) 2003 as the Year of Japan-ASEAN Exchange; 3) Japan-ASEAN Comprehensive Economic Partnership ${ }^{34}$; 4) An Initiative for Development in East Asia meeting to re-examine and consider future models of development; 5) A deepened security cooperation including new issues such as energy security.

4. Some proposals related to regional architecture: 1) An East Asia Community with ASEAN +3 plus Australia and New Zealand as core members and a close partnership with US. Later this initiative would evolve into the present East Asia Summit ${ }^{35}$; 2) A strengthening of ASEAN + 3 so that linkages could be created between Japan-ASEAN cooperation and the rest of East Asia.

The real novelties of Koizumi's proposals were: a renewed stress on security issues and the will to transfer Japan-ASEAN cooperation to other regions and multilateral fora.

Japan organized in December 2003 the ASEAN-Japan Commemorative Summit in Tokyo. The debates of the Summit were condensed in the "Tokyo Declaration", intended to be the roadmap of a renewed Japan-ASEAN partnership in the $21^{\text {st }}$ century. Its full name was

http://www.ukm.my/penerbit/akademika/ACROBATAKADEMIKA70/akademika70\%5B07\%5D.pdf; another detailed and complete analysis of Koizumi's foreign policy can be found in: Togo, Kazuhiko: "Greater SelfAssertion and Nationalism in Japan”, The Copenhaguen Journal of Asian Studies, no. 21 (2005).

${ }^{32}$ A good example of the expectations raised by that speech even before it was delivered is: Jain, Purnendra: "Koizumi's ASEAN doctrine", Asia Times, 10 January 2002.

${ }^{33}$ It was a crucial trip. Previously scheduled for September 2011, it was postponed because of the terrorist attacks in New York. During the following months Koizumi gave the impression of neglecting S.E.A. in order to forge close relationship with US.

${ }^{34}$ In Koizumi's vision this partnership would include cooperating in the new round of multilateral trade negotiations under the WTO.

35 Since the late eighties two different approaches to regional architecture in Asia-pacific have coexisted. The first one defends the centrality of ASEAN in any regional architecture. The second one, whose main proponents are Australia and Japan, prefers a broader construction, not centred in ASEAN and with some kind of US participation. In any regional architecture scheme Japan's priority is to avoid the hegemony of China. Therefore, Japan has consistently tried in all the processes to have Australia, India, New Zealand and, especially, US associated. 
"Tokyo Declaration for the Dynamic and Enduring ASEAN-Japan Partnership in the New Millenium". The Declaration insisted in the same issues and orientations set by Koizumi's Singapore speech. The main difference is that people-to-people and cultural relations received more attention that in the aforementioned speech $^{36}$. A Plan of Action was attached to the Declaration $^{37}$.

It is now the moment to turn to the two areas where Koizumi's impact was the most relevant: security issues and economic partnership.

\subsection{Security Issues}

In July 2004 Japan acceded to the Treaty of Amity and Cooperation with ASEAN (TAC) ${ }^{38}$. The reasons for the accession were: 1) ASEAN had made the accession to the Treaty a condition to participate in the East Asia Summit; 2) China had already acceded to the Treaty $^{39}$. In addition to this, acceding to the Treaty was consistent with the new stress in security issues and the traditional Japanese engagement in regional architectures processes.

In the field of security Koizumi's government paid special attention to the fight against maritime piracy and counter-terrorism.

The interest in piracy predated Koizumi ${ }^{40}$. In April 2000 Japan organized in Tokyo the Regional Conference on Combating Piracy and Armed Robbery against Ships. The 10 ASEAN countries were invited as well as India, Sri Lanka, Bangladesh, Korea, China and Hong Kong. The Conference adopted an Action Plan with guidelines to improve the cooperation between maritime policy authorities and private-sector maritime parties. As a follow up of the Conference, in the second half of the year Japan started exchange of information and technical assistance with Philippines, Malaysia, Singapore and Indonesia and a patrol vessel of the Japan Coast Guard held combined exercises with the Malaysian Navy aimed at combating piracy. In following years this combined exercises would extend to other ASEAN countries also.

Koizumi invigorated those efforts. As soon as he arrived in power, he proposed the establishment of a regional cooperation agreement against piracy. This initiative led to the signing of the Regional Cooperation Agreement on Combating Piracy and Armed Robbery against Ships in Asia (ReCAAP) in 2004. In 2006 a ReCAAp Information Sharing Center was launched in Singapore and the following year it was formally recognised as an international organisation. Presently there are 19 contracting parties to the ReCAAP ${ }^{41}$.

\footnotetext{
${ }^{36}$ Out of the 7 points included in the Declaration the 4th "Facilitating and Promoting Exchange of People and Human Resource development" and the $5^{\text {th }}$, "Enhancing Cooperation in Culture and Public Relations".

${ }^{37}$ It can be consulted at: http://www.asean.org/news/asean-statement-communiques/item/the-asean-japan-planof-action.

$\frac{}{38}$ The Treaty of Amity and Cooperation was signed in 1976 by the ASEAN members in order to secure peace and cooperation in the region. It created mechanisms to settle controversies. In 1987 it was opened to States outside of the region and later became a sine qua non to be accepted as member of the East Asia Summit.

${ }^{39}$ Kesavan, K.V.: "Japan and the ASEAN: Their Changing Security Relations", ORF Occasional Paper, no. 22 (August 2011).

${ }^{40}$ A good analysis of the geopolitical issues behind Japan's interest in the fight against maritime piracy can be found in: Bradford, John F.: "Japanese Anti-Piracy Initiatives in Southeast Asia: Policy Formulation and the Coastal States Responses", Contemporary Southeast Asia, vol. 26, no. 3 (2004).

${ }^{41}$ The contracting parties are: 9 ASEAN member countries (all of them except Malaysia), 3 East Asian countries (China, Korea and Japan), 3 South Asian countries (Bangladesh, India, Sri Lanka) and 4 European countries (Denmark, Netherlands, Norway and United Kingdom).
} 
Cooperation in counter-terrorism received special attention in the 2003 Plan of Action. It provided for the launching of a joint meeting on counter-terrorism, the supporting of the activities of the Southeast Asia Regional Centre for Counter-Terrorism in Malaysia and the training of law enforcement official from ASEAN member countries. On 2004 Japan and ASEAN adopted the ASEAN-Japan Joint Declaration for Cooperation to Combat International Terrorism. The dialogue on counter-terrorism started in 2005 and has been held annually since then, becoming a forum to enhance cooperation in the subject and to have a frank exchange of views on it. The Japan-ASEAN Integration Fund established in 2006 had a one of its targets to contribute to the counter-terrorism efforts.

Under Koizumi, Japan tried also to present itself as a provider of traditional security based on its Cambodian experience of the 90s. Japan dispatched forces for peacekeeping operations in Timor Leste in 2002 and also to Aceh in 2005 to assist to the recovery efforts after the 2004 tsunami. In 2005 japan participated for the first time in the US-Thai Cobra Gold exercise. It is remarkable that this contribution of Japan to the security in S.E.A. didn't provoke strong reactions anymore. On the other side, under Koizumi and in spite of his efforts, Japan was not able to play the kind of decisive role in the region it had played in the 90s.

\subsection{Economic Partnership}

Since his trip to the region in January 2002 Koizumi proposed a closer economic partnership with ASEAN and a deepened regional cooperation. This proposal led to the Initiative for Development in East Asia (IDEA) which held its inaugural Ministerial Meeting in August 2002 in Tokyo. IDEA focused on the new development challenges (human resources development, consideration to vulnerable members of society to counter the negative effects of globalization...) and on the need to create linkages between ODA, trade, investment and finance. The ideas promoted by IDEA were to be introduced into the existing processes (ASEAN + 3, Japan-ASEAN Framework Agreement on Comprehensive Economic Partnership...).

More important than IDEA in Koizumi's design was the Japan-ASEAN Framework Agreement on Comprehensive Economic Partnership (JACEP). JACEP aimed at the signing of a FTA between Japan and ASEAN. It was to complement and expand the bilateral EPAs (more about them below), pushing for a further liberalization of goods, services and investments. In order to understand fully the motivations behind JACEP, the general context must be considered: the ASEAN Free Trade Area was progressing; the ASEAN Community was expected to be created in 2015; there was a general movement towards the creation of free trade areas (APEC, TPP...). In November 2002 a Joint Declaration on the JACEP was issued and in October 2003 the Framework was signed. Negotiations started in earnest in 2005 and the Agreement was concluded in November 2007 and entered into force between 1 December 2008 and 1 January 2010 for the different countries ${ }^{42}$.

Nevertheless in a context of deepened competition for the S.E.A. markets with China ${ }^{43}$, a multilateral approach was not enough. Koizumi favoured the economic partnership

\footnotetext{
${ }^{42}$ The dates for the entry into force were: 1 December 2008 for Japan, Singapore, Laos, the Philippines, Vietnam and Myanmar; 1 January 2009 for Brunei; 1 February 2009 for Malaysia; 1 June 2009 for Thailand; 1 January 2010 for Cambodia.

${ }^{43}$ An overview of the economic competition between Japan and China in S.E.A. at the beginning of the 21 st Century can be found in: Avila, John Lawrence: "Torn between Two Lovers: ASEAN and its Evolving Economic Relations with China and Japan”, PASCN Discussion paper (2002-06).
} 
agreements (EPA), a broader kind of free trade agreement, as the tool to keep its economic position in S.E.A and, in addition, to strengthen its bargaining power in the WTO negotiations. The first EPA was signed with Singapore in January 2002. Singapore was chosen because of the nonexistance of an agricultural sector in the country and because of its role as a hub for ASEAN. By the end of Koizumi's mandate further EPAs had been signed with Malaysia and the Philippines and negotiations had been started with Brunei, Indonesia and Thailand.

\subsection{An Assessment of the Koizumi Years}

The Koizumi policy to S.E.A. was remarkable as it managed to keep Japan as a main player in the region and a increasingly relevant actor in security issues. Nevertheless it could not counterbalance the growing relevance of China. Factors beyond Koizumi's reach were at play, starting with the difference between China's vibrant and growing economy and Japan's stagnating one. So, in relative terms, Japan lost positions to China.

Nevertheless, different polls conducted immediately after Koizumi's tenure show a positive attitude of S.E.A countries to Japan as the wish to have Japan engaged in the region. A poll conducted by "Yoimuri Shimbun" in June/July 2006 showed that more than $90 \%$ of Indonesians, Malaysians, Thais and Vietnamese thought their country had good relations with Japan and between 70 and $90 \%$ thought Japan to be a trustworthy nation. However, when comparisons are made with China, China comes out on top, specially in Singapore, Malaysia and Thailand. Another survey conducted in 2008 by the Ministry of Foreign Affairs showed that economic and technological cooperation was the top area where ASEAN countries would like to see Japan engaged. Only $6 \%$ of respondents were eager to see Japan to enhance its military presence. Somehow the attempts by Koizumi to promote Japan as a security provider in S.E.A. were not completely successful.

\section{Japan and S.E.A.: Future Perspectives}

The seven years elapsed since the end of Koizumi's government have been marked in AsiaPacific by the geopolitical confrontation between an emergent China and a US that is back in the region with President Obama. In this context, the priorities for Japan have been: 1) To entertain the security linkage with US as a deterrent against China and DPRK; 2) To manage the relationship with China, developing economic and development ties, shelving historical and territorial issues and actively collaborating in regional for a; 3) To keep its position in S.E.A., as a way to enhance its international stature and to counterbalance China as well as to have a space of its own to avoid an excessive dependence on US.

The need to manoeuvre in S.E.A. between US and China, looking for an independent path has increase the relevance of ASEAN for Japan. A strong ASEAN that keeps its centrality in the regional architecture processes is seen by Japan as a must, as a way to cushion the contradictions between US and China and build a third ground where Japan can be a meaningful player. In this respect the ASEAN Community 2015 and its Interconnectivity Master Plan are important steps not only for the business opportunities they can offer to Japanese companies but also because an ASEAN economically integrated is a preferable option to an ASEAN whose members are dependent on their bilateral trade links with China. 
Even if the priorities were clear and the grasp of the geopolitical realities was accurate, the governments of the Democratic Party of Japan, that ruled Japan in the period 2009-2012, didn't introduce any new initiatives in S.E.A. and simply continued the policies implemented by the preceding governments of the Liberal Democratic Party (LDP). With a certain irony Peng Er Lam has written: “... the new DPJ government (...) has not repudiated the Fukuda Doctrine in its foreign policy pronouncements, possibly for want of a better doctrine" ${ }^{\text {44 }}$. This lack of new initiatives can be attributed to a complex political situation at home that absorbed the energies and precluded the formulation of a forceful and innovative foreign policy towards S.E.A.

The election of a new LDP government led by Shinzo Abe last December has created the expectation of a forceful comeback of Japan to S.E.A. Abe confirmed the expectations by choosing S.E.A. and not US as the destination of his first overseas trip as Prime Minister ${ }^{45}$.

The visit took Prime Mnister Abe to Vietnam, Thailand and Indonesia. In Jakarta, on January the $18^{\text {th }}$, Abe formulated the Five Principles that will lead Japan's ASEAN diplomacy:

1.- The protection and promotion together with ASEAN member states of universal values, such as freedom, democracy and basic human rights.

2.- To ensure that free and open seas are governed by laws and rules and to welcome the United States rebalancing presence in the region.

3.- The promotion of trade and investment, as well as the flow of goods, capitals, people and services, through various economic partnership networks.

4.- The protection and nurture of Asia's diverse cultural heritages and traditions.

5.- The promotion of exchanges among the young generations to foster mutual understanding.

The reaction to these principles has been muted in the best of cases. It has been stressed how the trip and the declaration showed Japan's will to continue being a main actor in ASEAN. Nevertheless, four issues can be raised about the Five Principles:

1) They lack the kind of broad and inspiring vision embodied in the Fukuda Doctrine or in the 2002 Koizumi address.

2) The mention to universal values as freedom, democracy and basic human rights may not be so welcomed by some ASEAN member states.

3) The reference to US would show a certain lack of self-confidence and may cast a shadow on the actual Japanese resolution to be its own man in the region.

4) Many have seen as a subtext to the declaration the will to contain an emergent China.

\footnotetext{
${ }^{44}$ Lam, op. cit.

${ }^{45}$ Singh, Bhubhindar: “New Japanese Premier's First Foreign Trip: Why SE Asia?”, RSIS (16 January 2013 ).
} 
We are yet at the beginning of Abe's mandate, but we have already got a first glimpse of what could be in store in the coming years: the continuation of Japan's efforts to remain a relevant and independent actor in S.E.A. 